\title{
Occurrence, Morphology and Chemical Composition of the Dufour Gland in Melipona bicolor Lepeletier, 1836 (Hymenoptera, Meliponini).
}

\author{
Fábio Camargo Abdalla* \\ Carminda da Cruz-Landim* \\ Graeme R. Jones** \\ * Departamento de Biologia, Instituto de Biociências, UNESP. Av. 24A, n. 1515, Bela Vista CEP \\ 13506-900, Rio Claro, SP, Brazil. \\ ** Department of Chemistry, Keele University, Staffordshire, ST5 5BG, UK.
}

The Dufour gland is an organ associated to the bee's female reproductive apparatus [1]. The gland produces mainly hydrocarbons and other organic oxygenated substances that play diverse pheromonal roles according to the bee ecology [2], but often related with reproduction. In eussocial bees its function is unknown, although probably is also involved in reproduction, marking queen's eggs [3] or indicating the queen reproductive status [4]. In order to throw some more light on the Dufour gland function in eussocial bees, it was done a study on the occurrence, morphology and chemical composition of this gland in workers and queens of Melipona bicolor, a polygynic neotropical stingless bee. The results showed that the Dufour gland was not present in workers. In virgin queens the gland cells showed characteristics of low activity, presenting few basal and apical plasmic membrane invaginations and few organelles in the cytoplasm (Fig. 1). In physogastric queens the gland epithelium was higher and the cells more active than in virgin queens, showing numerous basal plasmic membrane invaginations that formed a labyrinth, which was filled of an electrondense material (Fig. 2) and is involved with taking up substances from the haemolymph. The apical plasmic membrane invaginations were increased and the subcuticular space filled with material produced by the gland cells, which after will make part of the gland lumen secretion. Therefore, by the morphology view point the Dufour gland is more developed in physogastric than in virgin queens, what is in agreement with chemical analysis of the gland secretion, which showed that virgin and physogastric queen differ reasonably. The virgin queen secretion presents only hydrocarbons and the physogastric hydrocarbons and esters (Table I). The present results showed that this gland in $M$. bicolor is possibly involved in reproduction. According to preliminary bioassays the secretion allows the workers to distinguish the queens reproductive status and help the physogastric queens to recruit workers for the provisioning and oviposition process, known as P.O.P.

\section{References}

[1] C. da Cruz-Landim and F.C. Abdalla, Glândulas Exócrinas das Abelhas, 1th ed., FUNPECRP, Ribeirão Preto, 2002.

[2] A. Hefetz, 1987, Physiol. Entomol., (1987)12:243-253.

[3] T. Katzav-Gozansky et al., Naturwiess., (1997) 84:238-241.

[4] F.C. Abdalla and C. da Cruz-Landim, C., Avanços em Biologia Celular. Bauer, 1th ed., EDIPUCRS, Porto Alegre, 2002. 

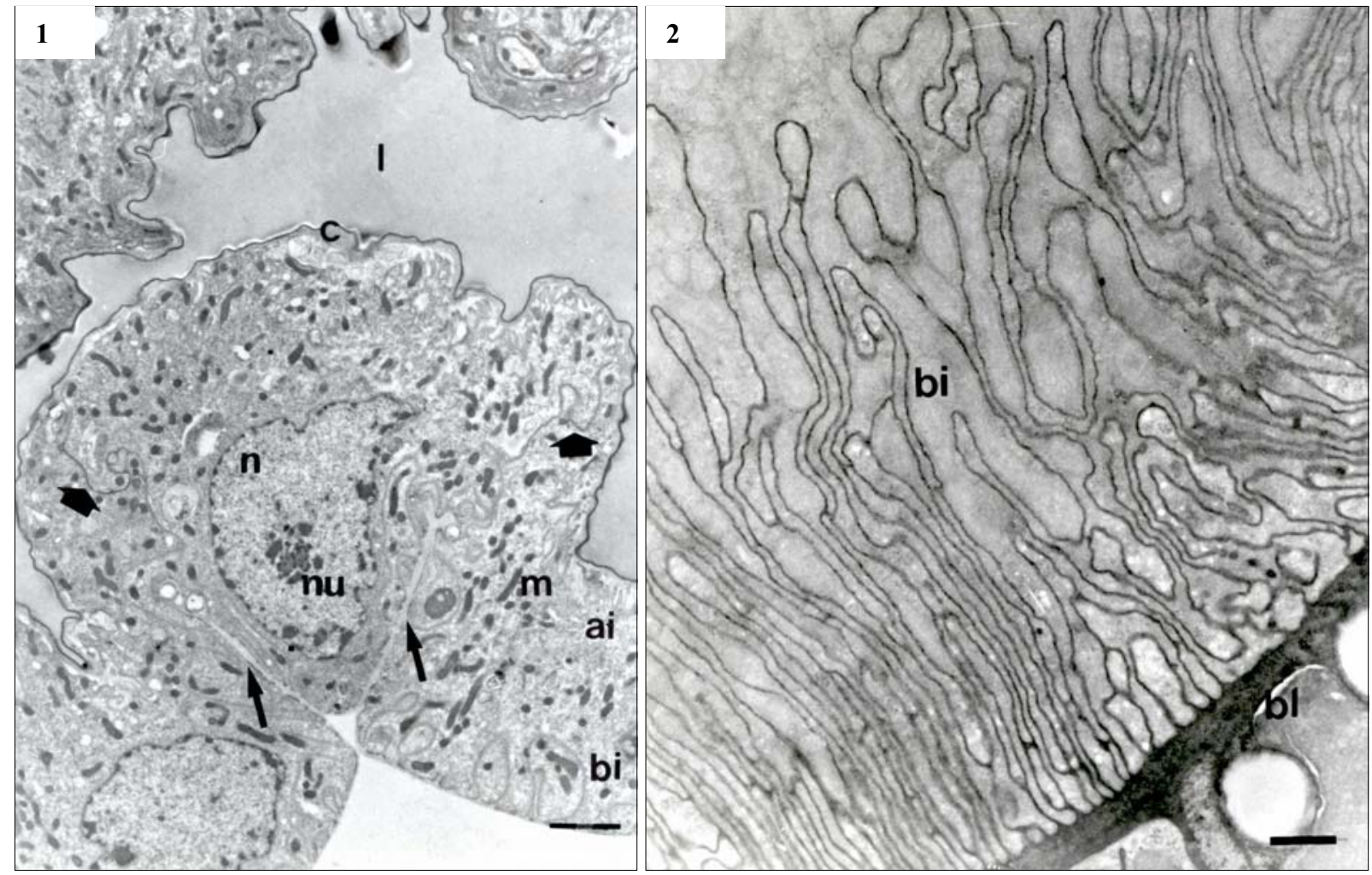

Transmission electron micrographs. 1. Detail of part of the epithelium of a virgin queen gland. Notice few basal (bi) and apical (ai) plasmic membrane invaginations, folds of the epithelium (arrows) and a sinuous cell contact (arrowheads). $\mathrm{m}=$ mitochondria, $\mathrm{n}=$ nucleus, $\mathrm{nu}=$ nucleoli. Scale Barr $=2 \mu \mathrm{m}$. 2. Detail of the basal portion of a physogastric queen gland, showing the numerous basal plasmic membrane invaginations (bi) forming a basal labyrinth impregnated with electrondense material. $\mathrm{bl}=$ basal lamina. Scale Barr $=1 \mu \mathrm{m}$.

Table I. The more abundant substances found in the Dufour gland secretion of virgin and phsysogastric queen of Melipona bicolor, by gas chromatography and mass spectrometry.

\begin{tabular}{lll}
\hline Substances & Virgin Queens & Physogastric Queens \\
\hline Hydrocarbons & & \\
\hline & C23 & C23 \\
& C25:1 & C25:1 \\
& C25 & C25 \\
& C27:1 & C27:1 \\
& C27 & C27 \\
& C29 & C29 \\
& C29:1 & C29:1 \\
\hline Esters & Absent & \\
& Absent & Dodecenyl Acetate \\
& Absent & Tetradecyl Acetate \\
& Absent & Dodecyl Isobutyrate \\
& Absent & Tetradecyl Isobutyrate \\
Absent & Farnesyl Acetate \\
Absent & Geranylgeranyl acetate \\
& & Diverse Terpenes \\
\hline
\end{tabular}

